\title{
ISSUES OF FOREST ENFORCEMENT AGAINST ILLEGAL LOGGING AND FOREST OFFENCES IN PENINSULAR MALAYSIA
}

\author{
MUHAMMAD NUR HANIFF MOHD NOOR, ROKIAH KADIR* AND SURIYANI MUHAMAD
}

Faculty of Business, Economics and Social Development, Universiti Malaysia Terengganu, Kuala Nerus, Terengganu

*Corresponding author: rokiah@umt.edu.my

Submitted final draft: 7 November $2020 \quad$ Accepted: 25 December $2020 \quad$ http://doi.org/10.46754/jssm.2021.10.019

\begin{abstract}
One of the more prevalent environmental issues in the world is illegal logging. Common outcomes associated with illegal logging, particularly in the states with rich forest resources, are environmental damage and loss of government revenue. Illegal logging and other forest offences can be curbed through internal regulatory measures, namely forest law enforcement. However, as past research has indicated, forest law enforcement may be hindered by issues and difficulties related to enforcement capacity. Analysis of these difficulties and challenges is needed to identify the loopholes and vulnerabilities in current enforcement practices. This study, therefore, aims to examine issues on enforcement capacity as perceived by the staff of enforcement agencies. A total of 240 frontline regulatory personnel from selected states in Peninsular Malaysia were administered a questionnaire. A small number of the respondents were later interviewed about the issues for additional insights. The data were analysed through the SPSS to examine the research question. The measures of central tendency revealed that some of the main challenges in relation to enforcement capacity of forest enforcement agencies include insufficient enforcement staff, lack of funding and insufficient equipment. The outcome of the study may increase awareness of policymakers regarding issues that affect forest law enforcement and help them formulate appropriate policy responses.
\end{abstract}

Keywords: Enforcement challenges, forest law, illegal logging, forest offences.

\section{Introduction}

Forests across the globe are greatly threatened by forest illegalities that occur at unsustainable rates. This issue is especially prevalent in developing countries in Africa, Latin America and Asia (World Bank, 2006). Forest illegalities are the unlawful harvesting, transportation, processing, and buying and selling of forest products. Factors driving the commission of these offences include corruption, lack of knowledge of forest laws, and high domestic and international demand for timber. Logging becomes illegal when timber is extracted in a quantity higher than authorized, when it is done without authorization, or when logging concessions are obtained through bribery (The Food and Agriculture Organization of the United Nations (FAO, n.d.). Illegal logging may be committed on a smaller scale for use as fuel and construction materials (Contreras-Hermosilla et al., 2007). Illegal timber harvesting may also be carried out on a larger scale for commercial purposes to generate profits (Kishor, 2012). Large-scale illegal logging may employ sophisticated machinery and equipment (Kishor \& Lescuyer, 2012), and are usually operated through organized crime syndicates (Mohd \& Yaman, 2001; Zakaria; 2016).

Illegal forest activities, including logging, can damage the environment. Illegal logging involves unsustainable practices that can endanger the balance in the ecosystem and biodiversity of forests. Some of the environmental impacts of these unsustainable activities are reduction of forest area, natural disasters and wildlife extinction. As studies have indicated, these activities can also cause extinction of flora and fauna, increase the occurrence of landslides and soil erosion, and contribute to climate change (FAO, 2005; Reboredo, 2013). Illegal forest encroachment also results in major floods that may destroy property and cause harm 
to vulnerable populations (Reboredo, 2013). In addition, illegal logging also affects a forest's function as a water catchment area (Kleinschmit et al., 2016).

Illegal logging and other forest offences can also affect the economy. These crimes result in loss of government revenue, as payments for associated taxes and premiums are evaded (FAO, 2005; Kleinschmit et al., 2016). The loss of government revenue from illegal timber harvesting is estimated at US\$10 billion per year (Nellemann, 2012). In addition, large-scale illegal logging has an adverse impact on the legal supply chain since it affects the price of legally felled logs. According to Hoare (2015), an estimated $35 \%$ of all timber production in Malaysia comes from illegal sources, while $10 \%$ of illegal timber in the international market originates from local forests. As such, these large-scale illegal operations will cause legal logging firms to earn reduced profits (Kleinschmit et al., 2016).

Forest illegalities occur in the tropical forest of the Amazon, Africa and Southeast Asia (United Nations Environment Programme (UNEP), 2012). The percentage of illegal logging from the total forest production in timber-producing countries across the globe is shown in Table 1. As can be seen, in some of these countries illegal logging accounts for a larger percentage of total forest production.
Reducing illegal forest activities requires effective forest law enforcement. Enforcement tasks include surveillance, monitoring, investigation, apprehension and prosecution of perpetrators (FAO, n.d.). In addressing illegal forest activities, enforcement strategies should take into consideration specific local and national conditions. Strategic efforts may include improving forest monitoring and information gathering (FAO, n.d.).

Enforcement agencies in developing countries are often faced with issues and challenges that may hinder effective forest law enforcement. One of the more crucial issues is insufficient enforcement capacity and resources (The International Criminal Police Organization (INTERPOL), 2013). Other issues causing failure of enforcement are inadequate frequency and lack of financial resources (Elias, 2012). Other challenges that contribute to poor forest enforcement include ineffective coordination between law enforcement agencies, ineffective long-term strategies, lack of effective mechanisms to address illegal logging and corruption (FAO, 2005).

A common limitation in forest enforcement capacity, as identified in INTERPOL's assessment, is the lack of adequate equipment. Equipment required for effective enforcement includes vehicles, fuel, GPS and detailed maps, cameras, flashlights, binoculars, radio equipment, mobile phones and protective

Table 1: Percentage of illegal logging from the total forest production in timber-producing countries in 2013

\begin{tabular}{lcc}
\hline \multicolumn{1}{c}{ Country } & Percentage of & Illegal Logging \\
\hline Brazil & 50 \\
Cameroon & 65 \\
Democratic Republic of Congo (DRC) & 90 \\
Ghana & 70 \\
Indonesia & 60 \\
Laos & 80 \\
Malaysia & 35 \\
Papua New Guinea & 70 \\
Republic of the Congo & 70 \\
\hline
\end{tabular}

Source: Hoare (2015) 
equipment. Computer hardware and software as well as information databases are also important to allow law enforcement to conduct intelligence-led enforcement activities, which can better facilitate the discovery of crime hotspots. Proper tools and equipment can help achieve two purposes: increase the likelihood of successful detection and improve the quality of evidence for successful prosecution (INTERPOL, 2013). As studies have indicated, in many cases even the most basic equipment is lacking, thereby affecting enforcement officers' ability to respond efficiently to forest violations. Equipment that is lacking includes vehicles, fuel, good maps and cameras. Implications arising from insufficient equipment include the inability to conduct surveillance and patrols, communicate effectively and track illegally logged timber. The situation is compounded when illegal activities are defended by armed guards (INTERPOL, 2013).

The effectiveness of forest law enforcement can be enhanced if enforcement teams have experienced, knowledgeable and skilled officers that can assist in developing new approaches (INTERPOL, 2013). These enforcement officers are especially needed when dealing with illegal loggers who can take unexpected actions to prevent being apprehended (INTERPOL, 2013). As enforcement of forest law is a complex and difficult task, deploying inexperienced officers can be a burden to an enforcement team and putting unnecessary pressure on other officers (INTERPOL, 2013). For example, inexperienced officers may fail to collect ample evidence and information, thereby impeding successful prosecution of illegal loggers (FAO, 2005).

In addressing illegal deforestation, enforcement strategies should be able to optimize resource use. According to research, full law enforcement strategy would not be viable, as it requires an extremely large number of resources. There is a better option, namely an incomplete law enforcement approach. For the method to be as effective as possible, it will require a strategic prioritization, which includes consideration of geospatial patterns of illegal activities. In
Brazil, for example, deforestation tends to occur in smaller patches in remote places. This information is used by forest law enforcement to target specific locations to optimize the deployment of costly field operations (Tacconi et al., 2019). In Myanmar, as research has indicated, more illegal logging occurs in areas closer to old footpaths before legal logging takes place. However, after the legal logging is completed, more illegal logging occurs closer to logging roads. Thus, legal logging operations unintentionally facilitate illegal logging, as illegal operators exploit the logging roads to transport their illegal harvest (Zar et al., 2018). Information on such spatial patterns can enable enforcement authorities to effectively tackle the identified location, thereby optimizing resource use. In Indonesia, illegal logging is more likely to occur in areas with relatively reduced tree cover and greater proximity to roads. Although monitoring the forests remains important to prevent occurrence of illegal harvesting, based on spatial analysis, it will be more costeffective if targeting illegal timber is conducted at storage sites rather than at logging sites. Storage sites are located at accessible places, which facilitate easier monitoring (Linkie et al., 2014). In Brazil, crimes involving treecutting and deforestation represent only $8 \%$ of illegal forest activities. This information is used by enforcement authorities to decide that the majority of monitoring is not carried out in the forests but is conducted on roads, near rivers and at logging companies' transport facilities (Brito \& Barreto, 2011).

Law enforcement effectiveness will be improved through a national strategy of enhancing coordination between different enforcement agencies (INTERPOL, 2013). This coordination will facilitate the planning of more effective enforcement activities that will help prevent, detect and suppress forest crimes more successfully (Lawson \& MacFaul, 2010). A multi-agency approach involving the police, customs, and financial and tax regulators to strengthen enforcement capacity has become more significant in recent decades, since forest crimes often involve other unlawful acts beyond 
the forestry sector, such as corruption, moneylaundering, fraud and violence (INTERPOL, 2013).

Improving forest law enforcement may also require the involvement of the public and non-governmental organizations, which assist government agencies, enforcement teams and legislative bodies in suppressing illegal logging (Goncalves et al., 2012). On the global scale, the public and NGOs have played significant roles in helping to detect large-scale illegal logging, raise public awareness about the impact of illegal logging and conduct studies on the effectiveness of enforcement activities (Goncalves et al., 2012).

In Malaysia, forest monitoring is under the jurisdiction of the state governments. The state forestry authorities have enforcement units, which are responsible for tasks associated with the prevention, detection and suppression of forest crimes (Mohd \& Yaman, 2001). The units oversee logging activities, examine timber licenses, inspect timber processing premises, verify the transport of forest products and investigate public complaints about forest crimes (Mohd \& Yaman, 2001).

As highlighted in the 2009 audit report, there were several failings in the practices of state forestry departments in Pahang, Sabah and Sarawak. These included weak enforcement and weak control of forest management (Hoare, 2015). To overcome these issues, the forestry authorities have recruited additional enforcement officers (Malaysia UN Report, 2012). However, the number of personnel and resources remain insufficient for effective enforcement, as statistics have shown (Hoare, 2015). From 1991-2016, although the number of reported cases of illegal logging in Peninsular Malaysia showed a decline, the number for other forest offences indicated an upward trend. Throughout the 26-year period, over 7,000 cases of forestry violations were reported (Forestry Department Peninsular Malaysia (FDPM), 2017).

This study aims to examine the perceptions of enforcement agency personnel on issues related to current enforcement capacity that may prevent them from effectively combating illegal logging and other forest offences in forest-rich states in Peninsular Malaysia.

\section{Materials and Methods}

The study was carried out in seven states in Peninsular Malaysia. These states were selected based on the size of their forest cover. The state with the smallest average area of forest cover is Selangor (250,860 hectares) and with the largest is Pahang $(2,068,500$ hectares $)$. The selection of the states also took into consideration the findings by Mohd Gani et al. (2013), which indicated that the occurrences of illegal logging in Pahang, Kelantan, and Terengganu were considerably higher. The selected states, the average area of their forest cover, and the area of Permanent Reserve Forest (PRF) are as shown in Table 2 .

Table 2: Area of forest cover and Permanent Reserve Forest (PRF) in selected states

\begin{tabular}{cccc}
\hline No. & State & $\begin{array}{c}\text { Average Area of } \\
\text { Forest Cover (hectares) }\end{array}$ & $\begin{array}{c}\text { Average Area of } \\
\text { (hectares) }\end{array}$ \\
\hline 1 & Pahang & $2,066,752$ & $1,562,631$ \\
2 & Kelantan & 819,339 & 625,504 \\
3 & Terengganu & 653,678 & 543,171 \\
4 & Johor & 461,833 & 427,250 \\
5 & Kedah & 341,284 & 339,799 \\
6 & Perak & $1,029,064$ & 994,208 \\
7 & Selangor & 250,860 & 250,129 \\
\hline
\end{tabular}

\footnotetext{
* Average area of forest cover and PRF from 2010 until 2016.
}

Source: Forestry Department Peninsular Malaysia (2010-2016) 
The study employed a close-ended questionnaire as the primary data collection method. The questionnaires were administered to more than 200 respondents from forestry enforcement agencies. A majority of the respondents $(88.4 \%)$ acquired high school education, and $86.8 \%$ were officers with ample working experience of more than 10 years. Items in the questionnaire were developed based on an in-depth analysis of past publications related to illegal logging. The questionnaire adopted a 5 -point Likert scale for the responses $(1=$ totally disagree, 2 = disagree, $3=$ neutral, $4=$ agree, $5=$ totally agree) which allowed stakeholders to rank their perceptions and opinions. The responses were analysed to obtain the values of measures of central tendency (mean, median and mode). These values enabled researchers to determine the significance of a specific item. The principal measure of central tendency to rank the importance of items in a questionnaire is the mean score $(\bar{x})$, with a high mean score indicating the significance of an item. In the case of skewed data, the preferred measure of central tendency will be the median.

Apart from the measures of central tendency, data were analysed to obtain the measures of dispersion in the form of standard deviation. Standard deviation (s) and variance $\left(\mathrm{s}^{2}\right)$ are the statistical tools that measure the spread of the dataset. A standard deviation with a value of more than 1 indicates skewed data, while standard deviation with a value close to
0 indicates clustered data. The reliability and validity of items in the questionnaire were confirmed based on the Cronbach value of 0.852 . The factor analysis was also executed during the pilot test. The outputs of factor analysis enabled researchers to group items into a proper construct and exclude unnecessary items which do not fulfil the condition of the analysis.

\section{Results and Discussion}

The overall findings of the study are in Table 3 . Based on the mean scores, the most crucial issues of enforcement capacity that influence the effectiveness of forest law enforcement in Malaysia, as perceived by respondents, are insufficient staff, financial constraints, funding, adequacy of facilities and equipment, and the current monitoring technology. On the other hand, issues perceived by respondents as posing less significant challenges towards forest law enforcement are vehicles, fuel, cameras and firearms.

Respondents identified the issue of insufficient staff $(\overline{\mathrm{x}}=4.40, \mathrm{~s}=0.60)$ as posing the greatest challenge towards forest law enforcement effectiveness. Based on the outcome of the study, the extent of understaffing within enforcement agencies may be regarded as chronic, whereby the current workforce is burdened with a massive workload. Insufficient human resources can impede the effectiveness of forest law enforcement. As revealed by

Table 3: Enforcement capacity and mean scores

\begin{tabular}{clcc}
\hline Item & \multicolumn{1}{c}{ Enforcement Capacity } & Mean & $\begin{array}{c}\text { Standard } \\
\text { Deviation }\end{array}$ \\
\hline 1 & Adequacy of facilities and equipment. & 4.18 & 0.83 \\
2 & Vehicles, fuel and camera. & 3.58 & 1.01 \\
3 & Latest monitoring technology. & 4.00 & 0.88 \\
4 & Firearms. & 3.53 & 1.00 \\
5 & Current funding. & 4.24 & 0.86 \\
6 & Effect of financial constraints. & 4.38 & 0.77 \\
7 & Sufficient funding and effective enforcement. & 4.20 & 0.66 \\
8 & Current staff. & 4.15 & 0.62 \\
9 & Effect of insufficient staff. & 4.40 & 0.60 \\
\hline
\end{tabular}


an INTERPOL needs assessment, there must be sufficient enforcement personnel with the necessary skills for enforcement to be effective (INTERPOL, 2013). Respondents agreed that there is a need to employ more enforcement staff for the agency to enhance the enforcement capabilities and efficiency. They indicated that enforcement activities could be impaired by insufficient human resources. Respondents 4 and 5 highlighted that most enforcement staff are approaching retirement age. This is an issue as forestry enforcement is a demanding occupation, whereby physical fitness is highly related to job performance. Respondents viewed that insufficient enforcement staff in the field compromised enforcement efforts. Inadequate manpower can lead to a stressful working environment because extra workload is placed on existing staff. The extra workload may in turn limit their capability to conduct monitoring and surveillance effectively. In some states, because there are insufficient foresters on duty, one officer is required to monitor approximately 6,000 hectares of forest. Respondents were also of the view that an insufficient number of enforcement officers could reduce the effectiveness of the timber tracking system. Examination of the total headcount did show that there was an inadequate number of enforcement staff at state forestry departments to conduct detection and enforcement patrols. There are 236 ground staff who are responsible for monitoring 4,916,748 hectares of forest and 522 operational wood processing mills, as well as 19 investigating officers, and 3 forensic personnel for the whole of Peninsular Malaysia. The inadequate number of staff poses a challenge, given that illegal loggers are operated by organized syndicates, employ well planned operations and use the latest equipment and communication devices (Mohd Nor \& Mahli, 2017). In addition, as highlighted by Hawari (2013), lack of forensic experts and insufficient skilled investigation officers present challenges towards crime investigation. These experts are needed to conduct forensic analysis of wood DNA, fingerprints, drink containers, machinery traces and other chemical substances found at illegal logging sites to gather the required identification information to support successful prosecution of the crime. Usually, only limited investigation resources - two to three officers - are allocated to state forestry departments. They are assisted by district and state assistant forestry officers, but these officers are also assigned to other tasks (Hawari et al., 2011). The lack of forensic expertise poses an issue, as prosecuting the offenders in court and ensuring that the conviction can be secured and the criminals punished requires reliable evidence. However, gathering of reliable evidence and technical information is affected by such insufficient numbers of forensic science experts and investigation staff (Hawari et al., 2011). Properly qualified and admissible expert testimony can provide strong evidence that will help identify a potential suspect to the exclusion of others. New investigation officers who lack the skills and knowledge tend to ignore many pieces of evidence such as oil barrels and food containers. In some cases, inexperienced raid teams fail to take pictures of items found, or they take pictures but fail to prove that the items were from the illegal logging sites. The scenario leads to a delay in the completion of investigation papers and an ineffective investigation process (Hawari et al., 2011; Sarip et al., 2011). Based on the result of the study, understaffing is the main challenge towards forest law enforcement. Hence, it may be suggested that the number of frontline enforcement officers needs to be reviewed by the forest authorities to cope with the ever-increasing demands of forest monitoring and surveillance (Pescott et al., 2010). The low inspector-to-site ratio will have an adverse impact on enforcement activities in the form of less frequent inspections, which will lower the detection rate of crimes (Boakye, 2020).

Investigations involve gathering evidence for a particular case. Evidence can be acquired through examination of the affected areas, documents, information from witnesses and suspects, as well as items related to the case (Hawari et al., 2011). An investigation paper is prepared for each case, which refers to records of documents, information management and evidence obtained from the investigation 
(Hawari et al., 2011). An investigation begins after a forest offence has been reported to the police. Based on a report, an investigating officer is appointed to look into the case (Hawari et al., 2011). However, the completion of an investigation paper can be affected by certain issues. For example, enforcement officers from district forestry authorities may not have sufficient knowledge about the procedures for reporting illegal logging or forestry offences, or police reports may not have been lodged within 24 hours of the detection of an offence and suspects have been arrested (Sarip et al., 2011). Investigation papers cannot be efficiently prepared when case information is insufficient (Sarip et al., 2011). Often, much of the information about the suspects is inaccurate and suspects are often not found at the addresses provided (Hawari et al., 2011). This can slow down investigations, especially when additional information is required. In practice most cases of illegal logging are detected only after the offences have been committed. Hence, no arrests can be made as only the stumps of trees are left at the sites (Hawari et al., 2011). With no arrests or solid evidence, the investigation officer may encounter difficulty tracking down suspects and preparing the investigation paper (Hawari et al., 2011). Issues may also arise in relation to falsification of machinery information. The chassis and engine number of machinery used for illegal logging may have been falsified, thereby causing difficulties in tracing their owners (Hawari et al., 2011).

Past studies emphasized the importance of ongoing training on intelligence, raids, and investigations (Christy et al., 2007; Hawari et al., 2011; Sarip et al., 2011). Recent studies also highlighted the importance of training on using technology to detect illegal logging (Ibrahim et al., 2011). Previous studies concurred that continuous training programmes should be provided to forest officials to enhance their skills, knowledge and leadership (Mohd \& Yaman, 2001). Forestry officials at the upper level need to be given training on law enforcement, investigation, and prosecution as well as court procedures (Mohd \& Yaman,
2001). Respondents agreed that, to enhance the effectiveness of enforcement, officers should be given adequate training. As concurred in the questionnaire feedback and interview, a majority of the respondents viewed that training should include matters related to crime detection and evidence collection. This finding is consistent with a previous study by Christy et al. (2007) on the importance of evidence-based training for enforcement officers to enhance the probability of successful prosecution. The training should also include preparation of prosecution and court procedures. As observed by Goncalves et al. (2012), most forestry officials are poorly trained on safeguarding evidence and obtaining information from witnesses. According to Christy et al. (2007), a wider scope of training may be necessary. Effective law enforcement requires training on legal aspects and prosecution procedures involving all levels of law enforcements, prosecutors, judges and NGOs that help monitor forests. Training of police officers positioned in areas with high frequency of illegal logging is equally important (Goncalves et al., 2012). Respondents agreed that training on the detection and collection of evidence provided to enforcement officer could be improved. Considerably high agreement was recorded for prosecutors be given training on case management.

Respondents agreed that funding issues posed great challenges towards forest law enforcement effectiveness. Effect of financial constraints had the mean score of 4.38 , and current funding had the mean score of 4.24. Respondents also agreed that the adequacy of facilities and equipment $(\bar{x}=4.18, s=0.83)$, an issue closely associated with financial constraints and limited funding, would substantially affect the effectiveness of forest law enforcement. The problem of insufficient equipment is attributable to the limited allocation for enforcement. In many countries, because of financial constraints, there are not enough financial resources for forest law enforcement action (Goncalves et al., 2012). Respondents agreed that enforcement teams did not have sufficient funding, and the inadequate budgets 
could negatively impact their capability to carry out enforcement activities. During interviews, respondents indicated that inadequate financial resources had restricted the acquisition of transport, surveillance and communication equipment they required. As earlier research has confirmed, the approved budget for some state forestry authorities for enforcement and investigation was limited despite the expansive workload of the department (Hawari et al., 2011). Enforcement costs for large and densely vegetated forest areas tend to be high because of the need for vehicles and other equipment, as well as salaries for a large number of patrolling officers. These costs form a significant portion of many forest management budgets. In India, approximately $60 \%$ of the forest department budget is spent on enforcement activities, that include salary costs and protection infrastructure (Robinson et al., 2010). In Peninsular Malaysia, the expenditure for staff emoluments and the procurement of assets in 2016 accounted for $63 \%$ (RM144 million) of the total disbursement by the Forestry Department (Forestry Department Peninsular Malaysia, 2016). In 2017, the department's expenditure for emoluments and the acquisition of assets increased to RM165 million (62\%) (Forestry Department Peninsular Malaysia, 2017). INTERPOL's analysis of forest enforcement capacity found that forest enforcement agencies needed more financial and technical resources are needed (INTERPOL, 2013). As highlighted by Pescott et al. (2010), limited funding and the high cost of acquiring equipment are the key constraints on forest law enforcement. However, acquisition of appropriate equipment and tools for enforcement have been proven to positively impact the detection rate (Pescott et al., 2010).

Respondents agreed that effective strategies were important, and the strategies adopted could affect enforcement effectiveness. They viewed the current enforcement strategies employed by the forest authorities as effective; nevertheless, they agreed that there were constraints the form of lack of equipment, funding and human resource. Interviewed respondents also highlighted lack of equipment as an issue faced by the agency. Respondent 1 observed that: "The enforcement agency does not have the necessary equipment. We always make proposals on this issue. We always raise the issue about insufficient equipment". Respondent 4 also noted that: "We do not have adequate facilities and manpower. Hence, we need to optimize available facilities and manpower. I think there is a need to improve our equipment. We encounter financial constraints to secure surveillance vehicles, GPS, cameras and other equipment. This issue is occasionally raised at our meetings. We do not have the funds to acquire the equipment. In previous cases, our staff took the initiative to use their personal equipment (like cameras)". Forest law enforcement officials in other countries also lack equipment to undertake effective enforcement in the field. In Indonesia, for example, lack of helicopters has rendered the enforcement agency not capable of carrying out enforcement despite having the $\mathrm{n}$ GPS coordinates of illegal activities (Goncalves et al., 2012).

Respondents agreed that coordination between enforcement agencies could enhance the effectiveness of forest law enforcement. Cooperation, such as with the police, could facilitate a multi-pronged strategy to combat the problem, thereby enabling the offenders to be charged with bigger crimes (Mohd \& Yaman, 2001). Police officers are empowered under Sections 88 to 93 of the National Forestry Act 1984 to arrest, search, make seizures and investigate. Respondent 2 from the interview concurred that cooperation between regulatory bodies could facilitate the utilization of assets, human capital and expertise of each agency to strengthen forest law enforcement. Some respondents highlighted the importance of the National Blue Ocean Strategy, which is a government strategy calling for cooperation between multiple ministries and agencies, as well as between all sectors and various stakeholders. The strategy aims to maximize impacts, minimize costs and enhance the progress of a particular project (Malaysia's National Blue Ocean Strategy, 2015). The strategy has enhanced cooperation between 
multiple law enforcement agencies. The primary agencies involved in the joint operation of forest law enforcement include the police, armed forces, anti-corruption agency and road transport authority.

Respondents generally agreed that participation of the public and NGOs is important for better control of illegal logging. Respondents' agreement reflects the significant role the public and NGOs play in assisting forestry authorities with detecting, suppressing and preventing illegal forest activities. Respondents' perception is consistent with past literature, which suggests that involvement from the public and NGOs could lead to more effective and efficient enforcement and detection of forest offences (Contreras-Hermosilla, 2002). NGOs and environmental groups can conduct regular monitoring to provide essential information on forest law violations (ContrerasHermosilla, 2002). In addition, as indicated in the latest Annual Report published by the Forestry Department Peninsular Malaysia (2014-2018), these groups organized awareness campaigns every year to raise public awareness on the importance of forests and environmental conservation.

Respondentsagreed that the latestmonitoring technology $(\overline{\mathrm{x}}=4.00, \mathrm{~s}=0.88)$ is a vital part of forest law enforcement, and its non-utilization may affect the effectiveness of enforcement. Respondents' agreement is consistent with past literature which suggests that forest monitoring is one of the integral components of effective forest law enforcement (Tacconi et al., 2019). An example of effective technology is aerial surveillance, which allows huge tracts of forests to be monitored quickly and with minimal staff (INTERPOL, 2013). Respondents agreed that the latest and up-to-date technology related to forest surveillance is important for improved detection of illegal logging. Organized crime has evolved, and illegal logging syndicates have developed various methods to avoid detection. Up-to-date and specialized equipment would enable enforcement team to stay one step ahead of the forest criminals (INTERPOL,
2013). The use of technology can help forest managers who require more intensive, precise and documented information on forest resources and landscape features (Khali Aziz, 2001). It also allows enforcement teams to monitor changes in forest cover in real time. Integrated technology comprising hyper-spectral imaging, forest monitoring using remote-sensing systems that uses satellite imagery, unmanned aerial vehicles (UAVs or drones), and a Geographical Information System (GIS) allows the authorities to obtain information quickly and accurately. Hyper-spectral imaging gathers and processes information from across the electromagnetic spectrum, while the GIS works with spatial and geographical data (Soo, 2017). These technologies enable enforcement teams to monitor the forests in better ways and take advantage of the increased transparency to take necessary actions (Cheung, 2015). The use of remote-sensing imagery, GIS and UAV, together with regular patrols and forest enforcement's integrated operations, has brought about positive impacts in terms of better detection rate of illegal logging and forest offences. Illegal logging cases were reduced from 42 in 2008 to only 1 in 2014 and collected number of compounds and fines for forest offences increased from RM0.99 million in 2008 to RM1.36 million in 2014 (Forestry Department Peninsular Malaysia, 2016).

This study found that respondents perceived firearms as presenting the least challenge towards forest law enforcement, as evidenced by its mean score being the lowest $(\bar{x}=3.53, s=1.00)$. However, the importance of firearms, should not be undervalued. llegal logging usually occur in remote areas and are committed by armed criminals (INTERPOL, 2013). Without protective equipment, forest officers can find themselves at a disadvantage and in grave danger. The potential risk of armed encounters may explain respondent's agreement with the need to equip officers in the field with firearms. As highlighted in an earlier study, investigation officers became demoralized when they faced dangerous illegal logging gangsters. Investigation officers may also be threatened 
indirectly when illegal operators threaten other parties. For example, they may warn vehicle owners not to rent out their "low loaders" to forestry officers for transporting illegal logging machinery from forests to storage sites for investigation and prosecution purposes (Hawari et al., 2011).

In practice, enforcement officers are equipped with pistols and shotguns to protect themselves against illegal loggers and forest criminals. In 2017, there were 81 firearms supplied to operational and enforcement units to be used during enforcement activities (Mohd Nor \& Mahli, 2017). In 2018, the number was increased to 106 (Sharifah Mahsinah, 2018). Most of the firearms (12 units) were delivered to Pahang, five to Selangor, and three to Kelantan and a few other states. Directors and officers were given pistols, while other members were given shotguns (Shamsul Kamal, 2015).

Respondents perceived issues regarding vehicles, fuel and cameras as posing less challenges towards forest law enforcement. These and other equipment, including firearms, drones, cones, measurement tools, vehicles and walkie-talkies are normally provided to enforcement teams. Respondents agreed that there were difficulties in securing, among other things, vehicles, fuel and cameras even though these are some of the required equipment for forest law enforcement. In 2017, there were only 38 vehicles provided to the operational and enforcement units to be used during enforcement activities (Mohd Nor \& Mahli, 2017).

Identification of significant challenges that hinder effective forest law enforcement will enable teams to focus on areas of weaknesses and vulnerabilities in enforcement and subsequently allocate appropriate resources to address the challenges, problems and issues. Ineffective enforcement affects governments financially. Illegal forest activities, including illegal logging, result in loss of government revenue because of tax and royalty payment evasion by illegal operators (FAO, 2005; Kleinschmit et al., 2016). At the global scale, the loss of government revenue in 2006 stood at an estimated US\$5 billion (World Bank, 2006). In 2016, the amount of the loss doubled to US\$10 billion (World Bank, 2016). In Peninsular Malaysia, the task of improving forest law enforcement is the responsibility of the state Forestry Departments (Mohd \& Yaman, 2001). The District Forestry Office is responsible for monitoring logging activities, inspecting licenses of wood-based industries, checking movement of forest produce, and investigating reports from the public regarding illegal forest operations (Mohd \& Yaman, 2001). The state governments also fund all expenses related to forest law enforcement activities (Jabatan Perhutanan Negeri Terengganu, 2019). In the long run, improved forest law enforcement by the state authorities may reduce the amount of government revenue loss.

\section{Conclusion}

Forest law enforcement plays an important role in safeguarding forests and ensuring sustainable harvesting. With enforcement in place, preventive measures can be taken, which include monitoring of non-compliance with forest-related rules and prosecution of those who violate those rules. More specifically, as part of safeguarding forests, enforcement teams carry out patrols or surveillance to detect criminal activities, the investigation of crimes, the arrest of offenders and prosecution of criminals. In carrying out their duties, forest authorities face multiple issues that may affect the effectiveness and efficiency of their enforcement activities. This study examined the issues and challenges of forest law enforcement from the viewpoint of enforcement personnel. The findings indicated that the issues associated with enforcement capacity are inadequate manpower, financial constraints to fund law enforcement activities, as well as lack of facilities and equipment. Insufficient manpower puts enormous pressure on the current staff and compromises monitoring and surveillance. Apart from forest patrols, chronic understaffing also occurs in the investigation and forest forensic departments. Lack of funding and limited allocation of 
equipment have restricted the mobility of enforcement teams. Inadequate transport, surveillance, and communication equipment also result in lower criminal detection rate. The identification of these challenges is likely to provide more awareness to policy planners and enable them to formulate appropriate policy responses towards these issues.

\section{Acknowledgements}

The researchers express their gratitude for the financial support from Malaysia's Ministry of Higher Education under the Fundamental Research Grant Scheme (FRGS) 59393.

\section{References}

Brito, B., \& Barreto, P. (2011). Enforcement against illegal logging in the Brazilian Amazon. Amazon Institute of People and the Environment.

Blaser, J. (2010). Forest law compliance and governance in tropical countries. A regionbyregion assessment of the status of forest law compliance and governance, and recommendations for improvement. FAO and ITTO.

Boakye, J. (2020). Enforcement of logging regulations in Ghana: Perspectives of frontline regulatory officers. Forest Policy and Economics, 11.

Cheung, L., Mason, J., \& Parker-Forney, M. (2015). Perimeter defense: 4 technologies for detecting and preventing illegal logging. World Resource Institute. https://www. wri.org/blog/2015/11/perimeter-defense4-technologies-detectingand-preventingillegal-logging

Contreras-Hermosilla, A. (2002). Law compliance in the forestry sector An overview. World Bank Institute. WBI Working Paper.

Christy, L. C., Leva, C. E. Di, Lindsay, J. M., \& Takoukam, P. T. (2007). Forest Law and Sustainable Development. Addressing
Contemporary Challenges through Legal Reform. The World Bank.

Elias, P. (2012). Logging and the law: How the U.S. Lacey Act helps reduce illegal logging in the tropics, 28. Food and Agriculture Organization of the United Nations.

(FAO). (2005). Best practices for improving law compliance in the forestry sector. Building (Vol. 145). FAO Forestry Paper.

Forestry Department Peninsular Malaysia (FDPM). (2016). Annual Report. Ministry of Natural Resources and Environment Malaysia.

Forestry Department Peninsular Malaysia (FDPM). (2017). Annual Report. Ministry of Natural Resources and Environment Malaysia.

Goncalves, M. P., Panjer, M., Greenberg, T. S., \& Magrath, W. B. (2012). Justice for forests. Improving criminal justice efforts to Combat Illegal Logging. World Bank Study.

Hoare, A. (2015). Tackling Illegal Logging and the Related Trade. Chatham House. The Royal Institute of International Affairs.

Hawari, Mohd Ali Hj, Deraman, Abdul Wahab, Sabran, Mohd Rizal, Sarpin, Mohd Rubaai., Mohd, Asmadi., Ibrahim, Zahari, \& Salleh, Mohd Syahrir. (2011). Cabaran dan keperluan asas dalam melengkapkan penyiasatan Kesalahan Hutan Seksyen 15 APN 1984. Proceedings of the 16th Malaysian Forestry Conference.

Ibrahim, Zahari., Mohd Nawi, Aida Farihan., \& Yusuf@Antik, Muhammad Ezhar. (2011). A new dimension on Forestry Legislation towards synergistic approach in strengthening enforcement activities: Issues and challenges. Proceedings of the $16^{\text {th }}$ Malaysian Forestry Conference.

Jabatan Perhutanan Negeri Terengganu. (2019). Sumber Peruntukan Kewangan. http:// trgforestry.terengganu.gov.my/index. php?option $=$ com_content\&view $=$ article $\&$ i $\mathrm{d}=399$ \&Itemid $=405$ \&lang $=$ my 
Kishor, N. (2012). Controlling illegal logging in domestic and international markets by harnessing multi-level governance opportunities. International Journal of the Commons, 6(2), 255-270.

Kishor, N., \& Lescuyer, G. (2012). Controlling illegal logging in domestic and international markets by harnessing multi-level governance opportunities. International Journal of the Commons, 6(2), 255-270.

Khali Aziz, H. (2001). Remote sensing, GIS and GPS as a tool to support precision forestry practices in Malaysia. Paper presented at the 22nd Asian Conference on Remote Sensing.

Kleinschmit, D., Mansourian, S., Wildburger, C., \& Purret, A. (2016). Illegal logging and related timber trade - Dimensions, drivers, impacts and responses. A GlobalmScientific Rapid Response Assessment Report. International Union of Forest Research Organizations (IUFRO) World Series, 35, $1-147$.

Lawson, S., \& MacFaul, L. (2010). Illegal logging and related trade, indicators of the global response. Chatham House .The Royal Institute of International Affairs.

Luttenberger, A., \& Luttenberger, L. R. (2017). Challenges in Regulating Environmental Crimes, 7th International Maritime Science Conference.

Linkie M., Sloan, S, Kasia, R., Kiswayadi, D., \& Azmi. W. (2014). Breaking the vicious circle of illegal logging in Indonesia. Conservation Biology, 28(4),1023-1033.

Mohd Nor, M. N., \& Mahli, A. R. ( 2017). Executive Talk 2017: Combating wildlife and forestry crime. Department of Wildlife and National Parks Peninsular Malaysia.

Mohd Gani, I., Mohd, L., Wahab, R., Sukhairi, M., \& Rasat, M. (2013). An overview of illegal logging situation in Peninsular Malaysia. Journal of Tropical Resources and Sustainable Science, 1(2), 24-30.
Mohd, Rusli \& Yaman, Amat Ramsa (2001). Overview of Forest Law Enforcement in Peninsular Malaysia. World Wildlife Funds (WWF)-Malaysia, Kuala Lumpur.

Mohammed, S., \& Danjuma, M. N. (2014). Linking participatory rural appraisal to forest protection and conservation in Katsina State of Nigeria. European Scientific Journal, 10(20), 244-262.

Malaysia UN Report. (2012). National Report to the Tenth Session of the United Nations Forum on Forests: Malaysia, 2012. http:// www.un.org/esa/forests/pdf/national reports/unff10/Malaysia.pdf.

Nellemann, C. (2012). Green Carbon, Black Trade: Illegal logging, tax fraud and laundering in the world's tropical forests. A Rapid Response Assessment. United Nations Environment Programme.

Nature Economy and People Connected (NEPCon). (2018). Timber Legality Risk Assessment Malaysia-Peninsular. Version 1.3. Country Risk Assessments.

Pescott, M. J., Durst, P. B., \& Leslie, R. N. (2010). Forest law enforcement and governance: Progress in Asia and the Pacific. Asia- Pacific Forestry Commission. Food and Agriculture Organization of The United Nations. Regional Office for Asia and The Pacific.

Rhodes, W. M., Ph, D., Allen, E. P., \& Callahan, M. (2006). Illegal logging: A market-based analysis of trafficking in illegal timber. Trends in Organized Crime, 10(1), 61-64.

Robinson, E. J. Z., Mahaputra, A. K., \& Albers, H. J. (2010). Protecting developing countries' forests: Enforcement in theory and practice. Journal of Natural Resources Policy Research, 2(1).

Reboredo, F. (2013). Socio-economic, environmental, and governance impacts of illegal logging. Environment Systems and Decisions, 33(2), 295-304.

Shamsul Kamal, A. (2015). Keep off forest reserves if you don't have permits, adrenalin 
junkies told. New Straits Times. https://www. nst.com.my/news/nation/2018/01/328758/ keep-forest-reserves-if-youdont-havepermits-adrenalin-junkies-told

Sharifah Mahsinah, A. (2018). Forestry enforcement officers warned not to misuse their firearms for their benefit. New Straits Times. https://www.nst.com.my/ news/nation/2018/03/342114/forestryenforcement-officerswarned-not-misusetheir-firearms-their

Sarip, Khairil., Mohd Sukri, Azuan., Jamel, Mohd Firdaus., Samsudin, Mohd Hafiz., \& Abdullah, Mohd Khairul. (2011). Penyelesaian dalam Melengkapkan Siasatan Kes Kesalahan Hutan: Isu dan Penambahbaikan. Proceedings of the 16th Malaysian Forestry Conference.

Soo, W. J. (2017). Malaysia recorded RM15.2 million in losses due to illegal logging. New Straits Times. https://www.nst.com. my/news/nation/2017/08/268225/malaysiarecorded-rm152-million-losses-due-illegallogging

Tacconi, L., Rafael J. Rodrigues, R. J., \& Maryudi, A. (2019). Law enforcement and deforestation: Lessons for Indonesia from Brazil. Forest Policy and Economics.

The Food and Agriculture Organization of the United Nations (FAO). (n.d.). Forest
Law Enforcement. http://www.fao.org/ sustainable-forestmanagement/toolbox/ modules/forest-law-enforcement/basicknowledge/en/?type $=111$

The International Criminal Police Organization (INTERPOL). (2013). Assessment of Law Enforcement Capacity Needs to Tackle Forest Crime. Environmental Crime Programme. Project Leaf.

World Bank. (2006). Strengthening Forest Law Enforcement and Governance: Addressing a Systematic Constraint to Sustainable Development. Environment and Agriculture and Rural Development Departments.

World Bank. (2016). World Bank Group. Forestation Plan. FY16-20. International Bank for Reconstruction and Development.

Zakaria, Rosli. (2016). License owning of chainsaws to curb illegal logging. New Straits Times. https://www.nst.com.my/ news/2016/07/156202/licenseowningchainsaws-curb-illegal-logging

Zar, C. W., Mizoue,N., Ota, T., Wang, G., Innes, J. L., Tsuyoshi Kajisa, T., \& Yoshida, S. (2018). Spatial and temporal patterns of illegal logging in selectively logged production forest: A case study in Yedashe, Myanmar. Journal of Forest Planning, 23(2). 